\title{
Marine Ornamental Trade in Brazil
}

\author{
J.L. GASPARINI ${ }^{1}$, S.R. FLOETER ${ }^{2, *}$, C.E.L. FERREIRA ${ }^{3}$ and \\ I. SAZIMA ${ }^{4}$ \\ ${ }^{1}$ Departamento de Ecologia e Recursos Naturais, Universidade Federal do Espirito Santo, Caixa \\ Postal 5130, 29041-970 Vitória, ES, Brasil; ${ }^{2}$ Laboratório de Ciências Ambientais, Universidade \\ Estadual doNorte Fluminense, Av. Alberto Lamego, 2000, 28013-600 Campos dos Goytacazes, RJ, \\ Brasil. *Present address: National Center for Ecological Analysis and Synthesis, University of Cal- \\ ifornia, Santa Barbara. 735 State Street Suite 300, Santa Barbara, CA 93101-5504, USA; ${ }^{3}$ De- \\ partamento de Oceanografia, IEAPM Rua Kioto 253, 28930-000 Arraial do Cabo, RJ, Brasil; \\ ${ }^{4}$ Departamento de Zoologia e Museu de História Natural. CaixaPostal 6109, Universidade Estadual \\ de Campinas, 13083-970 Campinas, SP,Brasil; *Author for correspondence (Present address: \\ National Center for Ecological Analysis and Synthesis, University of California, Santa Barbara, 735 \\ State Street, Suite 300, Santa Barbara, CA 93101-5504, USA; e-mail: floeter@nceas.ucsb.edu; \\ phone: (805)-882-9218; fax: (805) 892-2510)
}

Received 21 October 2003; accepted in revised form 13 April 2004

Key words: Aquarium reef trade, Brazil, Condylactis gigantea, Local extinction, Marine ornamentals, Reef fish

Abstract. Brazil is one of the five leading exporting countries of tropical aquarium fishes in the world, and the interest in marine ornamental organisms has increased substantially there from the mid to the late 1990s. About 120 reef fish species are currently harvested in Brazil's ornamental trade. Among the 75 most harvested species, $26(34.7 \%)$ are endemic, eight $(10.7 \%)$ are rare, and six $(8.2 \%)$ are estuarine-dependent species. Fifty-five species $(75.3 \%)$ have complex reproductive strategies and/or parental care. In quantitative terms, the top 10 species comprises $62 \%$ of the species exported from Brazil to the USA and the European Community. The most harvested reef invertebrates include about 65 species. The most representative groups are crustaceans with 15 species $(23 \%)$, and molluscs and stony corals with 10 species (15.4\%) each. Among these, $15(23 \%)$ are endemics, nine $(13.8 \%)$ are rare species, and seven (10.8\%) are important reef builders. A case of local extinction of the giant anemone Condylactis gigantea is reported. To alleviate ecological impacts a series of urgent measures is suggested, including the creation of specific laws for marine ornamental harvesting and improving law enforcement to prevent illegal trade in Brazil.

\section{Introduction}

The global aquatic ornamental trade, including both freshwater and marine organisms as well as aquarium products, was worth about one billion US dollars in 1993 (Chapman et al. 1997). The marine portion accounts for 10$20 \%$ of the total value of the ornamental industry (Andrews 1990), comprising $4-10 \%$ of the fishes traded (Biffar 1997; Sadovy and Vincent 2002). Nearly all marine aquarium fish and invertebrate species are still harvested from the wild (Friedlander 2001; Wood 2001a), and the increase in collection rates leads us to dispute the sustainability of the marine ornamental trade. Due to the highly selective nature of this activity and to the large numbers of individuals 
collected, the potential for over-exploitation is high (Wood 1985, 2001a; Sadovy and Vincent 2002).

The global import value of marine fish and invertebrates for the aquarium trade is estimated to be US\$ 24-40 million annually (Wood 2001a). Overall, this figure has apparently remained fairly stable in recent years. The USA is the main import market for aquarium species (marine and freshwater), followed by the European Community and Japan (Davenport 1996; Wood 2001a). Currently, as many as 24 million reef fishes belonging to about 1470 species are currently collected yearly to supply private and public aquaria around the world (Wabnitz et al. 2003). Marine ornamental species come from about 80 countries, the most important suppliers being Indonesia and the Philippines, but Brazil, the Maldives, Vietnam, Sri Lanka and Hawaii (USA) also supply impressive numbers (Wood 2001a; Sadovy and Vincent 2002).

During the last 5 decades, the Brazilian coast has experienced intense industrialisation and chaotic urban development, seriously affecting all coastal ecosystems including reef systems (Leão and Dominguez 2000). Other human economic activities have direct impacts on reefs, one of which is the harvesting of organisms for the ornamental trade. However, very few reports are available on this activity in Brazil (IBAMA 2000; Monteiro-Neto et al. 2000, 2003). The country is one of the five leading exporting countries of tropical aquarium fishes in the world (freshwater and marine), with exports worth US\$ 3.5 million in 2000 according to the Brazilian Trade Ministry (Ministério do Desenvolvimento, Indústria e Comércio Exterior - http://www.mdic.gov.br). Even though most of the trade focuses on freshwater fishes, the interest in marine aquarium organisms has greatly increased in the last few years (Monteiro-Neto et al. 2000, 2003). In this paper the current knowledge on the marine ornamental trade in Brazil is synthesised for the first time, including selected data on the most harvested species. The most urgent management and conservation measures for these renewable resources are suggested.

\section{Ornamental reef trade in Brazil}

There are no official statistics on the ornamental marine trade in Brazil. The Global Marine Aquarium Database (GMAD - http://www.unep-wcmc.org/ marine/GMAD) is one of the few sources of information. Although numbers are clearly underestimated (see below), the database is a useful tool to identify trends on fish and invertebrate organisms exported from Brazil to the USA and the European Community. For example, according to the GMAD, Brazil alone supplies one-third to almost half of the combined North American and European trade of many reef fish species (e.g. the angelfishes Pomacanthus paru, Holacanthus tricolor, H. ciliaris). However a huge discrepancy in numbers is found. For example, in contrast to the nearly 2200 French angelfish (Pomacanthus paru) reported in the GMAD as imported by the United States and Europe, export figures reported by Monteiro-Neto et al. (2003) for this species 
for the Ceará State only are over 10 times higher (22,969 - data come from the same years, 1995-2000). The general fish imports increased threefold from 1995-1997 to 1999-2000 according to GMAD, but exports from the Ceará State increased six- to eightfold in the same period.

About 120 reef fish species are currently in the aquarium trade in Brazil (IBAMA 2000; Monteiro-Neto et al. 2003; authors' personal observations 2003), and we present herein a list of the most harvested ones (Table 1, Appendix 1). In quantitative terms, species that rank among the most imported by the USA and the European Community are also found to rank among the most important species traded at four Brazilian States that we have information on (Table 1). In the Ceará State (NE Brazil) the top 10 species made up $72 \%$ of the total trade between 1995 and 2000 Monteiro-Neto et al. 2003). The same 10 species comprises $62 \%$ of the species exported from Brazil to the USA and the EU (Table 1).

For the number of species richness in the trade, the most representative families are wrasses (Labridae: nine species), damselfishes (Pomacentridae: eight), and angelfishes (Pomacanthidae) and butterflyfishes (Chaetodontidae) with five species each (Appendix 1). Among these four families, 26 species $(34.7 \%)$ are endemics with five species still scientifically undescribed ("new species"). Eight (10.7\%) are rare species, and six (8.2\%) are estuarine-dependent species. Fifty-five species $(75.3 \%)$ present particular reproductive strategies and/or parental care.

The most harvested reef invertebrate organisms in Brazil comprise about 65 species (Appendix 2). The most representative groups are the crustaceans with

Table 1. The most important reef fish species in the aquarium trade at four Brazilian States.

\begin{tabular}{lrrrrc}
\hline Species & GMAD $^{\mathrm{a}}$ & Ceará $^{\mathrm{b}}$ & Pernambuco $^{\mathrm{c}}$ & Bahia $^{\mathrm{c}}$ & Espírito Santo $^{\mathrm{c}}$ \\
\hline Hippocampus spp. $^{\mathrm{d}}$ & 1 & 3 & 1 & 5 & 5 \\
Gramma brasiliensis $^{\mathrm{d}}$ & 2 & 5 & 2 & 4 & 1 \\
Holacanthus ciliaris $^{\text {Centropyge aurantonotus }}{ }^{\mathrm{d}}$ & 3 & 1 & 3 & 2 & 2 \\
Pomacanthus paru $_{\text {Elacatinus figaro }}^{\mathrm{d}}$ & 4 & 8 & & 3 & 7 \\
Holacanthus tricolor $_{\text {Acanthurus coeruleus }}$ & 5 & 2 & & 1 & \\
Bodianus pulchellus $_{\text {Pomacanthus arcuatus }}$ & 6 & 7 & & & 3 \\
\% of total trade & 7 & 6 & 4 & & 6 \\
Year & 9 & 10 & & & \\
\hline
\end{tabular}

The ranking of species at all sites follows that of the imports by the USA and EU from Brazil. Sources: (a) Global Marine Aquarium Database (http://www.unep-wcmc.org/marine/GMAD); (b) Monteiro-Neto et al. (2003); (c) IBAMA (2000); (d) Endemic to the Brazilian marine biogeographic province or to Brazil's coast plus the southern tip of the Caribbean; (e) The goldentail moray (Gymnothorax miliaris) figures in the top 10 GMAD list but was here excluded from the analysis because it was considered to represent an unusual shipment in the year 2000, since it is not among the top species in neither Brazilian State nor in other years searched in the GMAD; NA = data not available. 
15 species $(23 \%)$, and mollusks and stony corals with 10 species $(15.4 \%)$ each. Among these species $15(23 \%)$ are endemics, nine (13.8\%) are rare species, and seven species $(10.8 \%)$ are important reef builders. Only large gastropods are listed in Appendix 2, but an equally important (if not larger) and specialised market is maintained by amateur and professional malacologists. This trade promotes intense gathering of several smaller gastropods and bivalves ( $\mathrm{R}$. Absalão, personal communication 2002).

\section{Main harvesting areas}

The six Brazil's States in which marine ornamentals are most heavily harvested are presented here from north to south along the coast, and briefly discussed below (Figure 1). In the northeast coast, the Ceará State is the major export site, the dealers receiving the production from neighbour States. A total of 199,304 reef fishes were traded through Fortaleza (main Ceará city) market from 1995 to 2000 (Monteiro-Neto et al. 2003). However, the Ceará State is also an important collecting ground, heavily harvested places including the "Pedra da Risca do Meio", a Marine Protected Area (Nottingham et al. 2000). The neighbouring Rio Grande do Norte State recently started to harvest seahorses, mostly from mangrove channels (Dias et al. 2002). Still in the northeast, the Pernambuco State suffers from severe overexploitation of reef organisms due to the easy access to the coastal fringing reefs (B.P. Ferreira, personal communication 2002). In the east, the Bahia State has four exporting facilities, the Baía de Todos os Santos being an important collection area close to main city, Salvador. There are 25 wholesalers licensed by the Instituto Brasileiro do Meio Ambiente e dos Recursos Naturais Renováveis (IBAMA) in these four northeast States (Figure 1).

In the southeast, the Espírito Santo State leads the harvesting of marine organisms. These are principally extracted from the many coastal islands, submersed rocky reefs and extensive calcareous algae (rhodoliths) beds. This state is the main producer of 'live rock', with 29 licensed wholesalers. Also in the southeast, the São Paulo State exported 184,070 fishes through 14 wholesalers between 1998 and 2000, according to official data. However, it has the distinction of being the only Brazilian State that created official rules for the ornamental trade, such as the establishment of collecting quotas and minimum standards for handling and transport of reef fishes (IBAMA 2000). There are 35 wholesalers licensed by the IBAMA in these two southeast States (Figure 1).

\section{Harvesting methods}

Inadequate and poorly adapted vessels from conventional and/or artisanal fisheries are largely used for collection of marine ornamentals. The boats are generally equipped with old 'narghile' gear (surface demand), usually in bad 


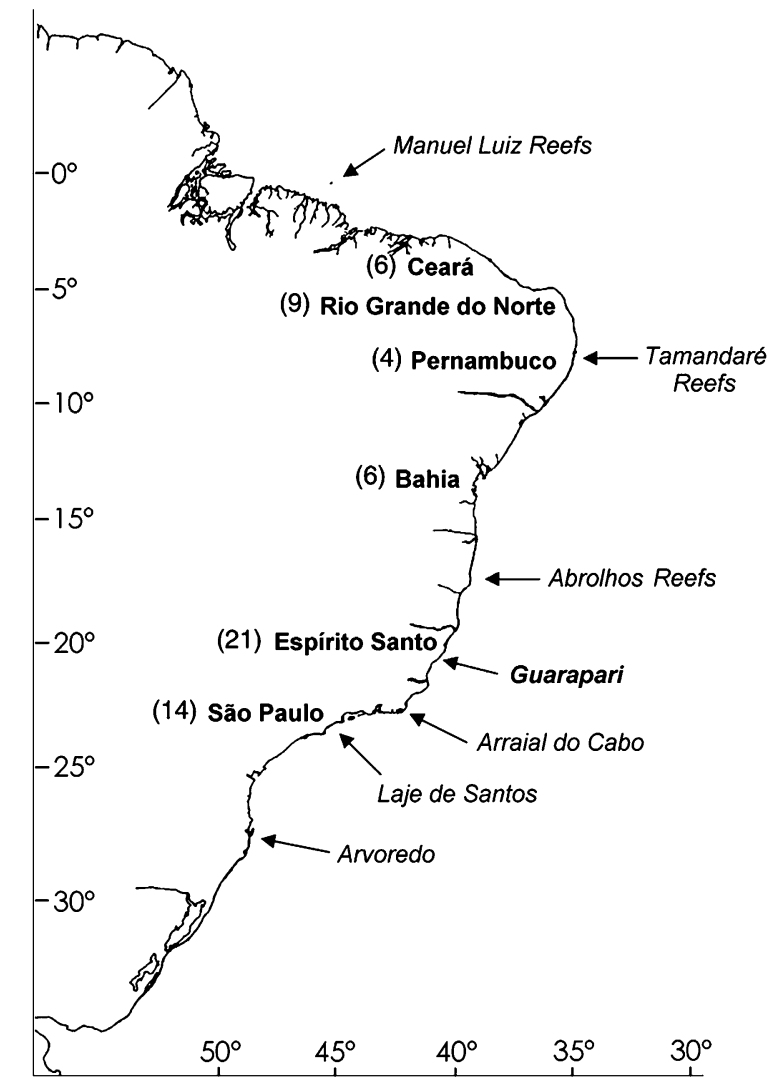

Figure 1. Main harvesting areas and sites sampled along the Brazilian coast. Main harvesting areas shown inside the continent with number of licensed wholesalers; sites sampled along Brazilian coast indicated with arrows; Guarapari Islands (collection site of data in Figure 2) shown in bold.

condition. The crew is often composed of three people, one controlling the air compressor and the other two diving (Nottingham et al. 2000). Hand nets are the main gear used for harvesting while underwater. At shallow sites, smallmesh cast-nets are sometimes used (small hand nets are used in tide pools, and cast-nets are used in mangrove systems). Invertebrates harvested for the ornamental trade are collected with hand nets or by hand. Those taken for the souvenir trade are pulled out manually (e.g. coral heads) or with the aid of iron bars (JLG personal observations 1991-1998). With few exceptions fishes are inadequately handled and stored. Poor water quality and handling, along with accompanying stress and disease are the causes of high mortality rates (see Wood 2001a; Sadovy and Vincent 2002). Mortality immediately after collection and in holding tanks prior to exportation is estimated to be at least 3040\% (JLG personal observations 1995-2003). 
Among the most harvested reef fishes for the aquarium trade in Brazil, nine species $(12 \%)$ are also harvested for food or are caught as a by-catch by trawling. Six other species $(8 \%)$ are subject to three different harvesting methods (Appendix 1). Twenty species $(26.7 \%)$ are considered to suffer high harvesting pressure from the aquarium trade, based on their importance ranking in the trade (Table 1), price and/or rarity.

Among the reef invertebrate species, $14(21.5 \%)$ are harvested by at least two different markets, aquarium and curio trade, 12 of which are considered to suffer from high pressure from one of these types of harvesting (Appendix 2). Five species $(7.7 \%)$ are also caught as a by-catch product from trawling activities.

\section{The impacts of harvesting}

The effects of removing ornamentals on ecological processes are largely unknown. For example, angelfishes may represent a true 'keystone guild' (Hill 1998) and their effect on community structure might be greater than their numbers (abundance) suggest. Thus, the possible effects of widespread angelfish harvesting on reef communities should be seriously considered.

The fire corals (Millepora spp.) provide a good illustration of how collecting affects the physical structure of the reef. Collectors sometimes inadvertently break coral while attempting to corner a fish or prevent its escape (Wood 2001a). For example, the yellowtail damselfish Microspathodon chrysurus (Appendix 1) tends to dwell close to branching colonies of fire corals (Millepora spp.) and retreats within the branches when threatened, in a fashion similar to that recorded for the Indo-Pacific three-stripe damsel Dascyllus aruanus (Edwards and Shepherd 1992). In Brazil, extensive damage to the coral colony is frequently done while harvesting the yellowtail damselfish, as the corals are often deliberately smashed and fishes hiding amongst the branches are 'shaken out' into plastic bags.

Despite a dispersal phase at the planktonic larval stage, most coral reef fishes are rather sedentary after settlement and have a relatively small home range (Leis 1991; Friedlander 2001). Moreover, self-recruitment is considered important in some species (e.g. Leis 2002). Site fidelity is a serious problem when heavy harvesting is exerted on a small area for a long time, a problem aggravated by the selective removal of a few target species. We expect harvesting pressure to be lower in areas away from the coast, due to the progressive access troubles (local scale), and at marine protected areas along the coast (regional scale). To test this hypothesis, densities of angelfishes (Pomacanthidae, a highly targeted fish family by the ornamental trade) were censused at three sites with progressively greater distances from the coast near Guarapari, Espírito Santo State in SE Brazil. Replicated visual transects $(20 \mathrm{~m}$ long and $2 \mathrm{~m}$ wide $=40 \mathrm{~m}^{2}$ ) using SCUBA diving were performed in each site from January to April 2001 (details in Floeter 2003). Densities of the smaller 
size classes (juveniles and sub-adults) were greater at progressively greater distances from the coast (Figure 2). The trend we found is consistent with our suggestion that harvesting is greater in coastal areas and that it has the potential to reduce the overall abundance of the harvested species at local scales. These results are not to be confounded with natural variation due to habitat characteristics (authors' personal observations), since we also found that the larger size classes of these fishes (adults usually not targeted by the trade) were present in approximately equal numbers at the three sites, a strong indication that these species would be found in similar numbers at all sites were not for harvesting trade. The differences in Figure 2 exemplify the greatest pressure exerted upon the small size classes (more suitable for the trade).

On a larger scale pattern, we recorded differences in the relative abundance of the French and the grey angelfishes (Pomacanthus paru and P. arcuatus, respectively) along the Brazilian coast (Figure 3). Although a decrease in abundance with increasing latitude is expected for this spongivore-herbivore genus (Harmelin-Vivien 2002; Ferreira et al. 2004), sites that are not protected by marine reserves show much lower abundances than would be predicted by their latitudinal position.

Endemic species that present very restricted distribution ranges or small populations are especially vulnerable to local extinction (Hawkins et al. 2000). Even ornamentals from remote reefs or oceanic islands are not free from harvesting. For example, heavy collecting severely reduced the endemic

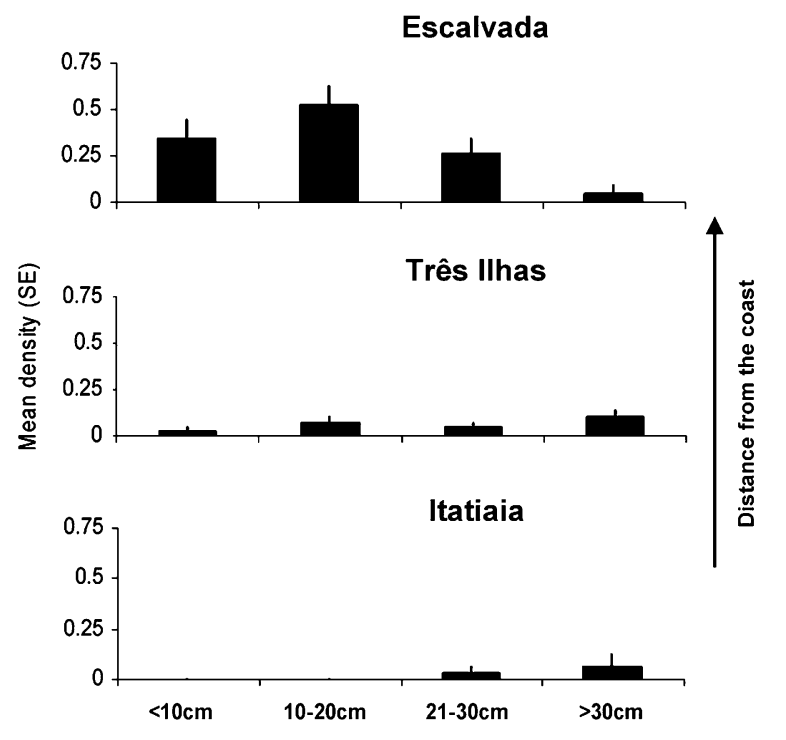

Figure 2. Angelfish (Pomacanthidae) mean densities and standard error in four size classes at three island sites near Guarapari (Espírito Santo, SE Brazil). Fish were censused in strip transects of $20 \times 2 \mathrm{~m}$ (Itatiaia, $\mathrm{N}=39$; Três Ilhas Archipelago, $\mathrm{N}=72$; Escalvada Is., $\mathrm{N}=55$ ). Distance from the coast: Itatiaia $=0.5 \mathrm{~km}$, Três Ilhas $=3.5 \mathrm{~km}$, Escalvada $=11 \mathrm{~km}$. 


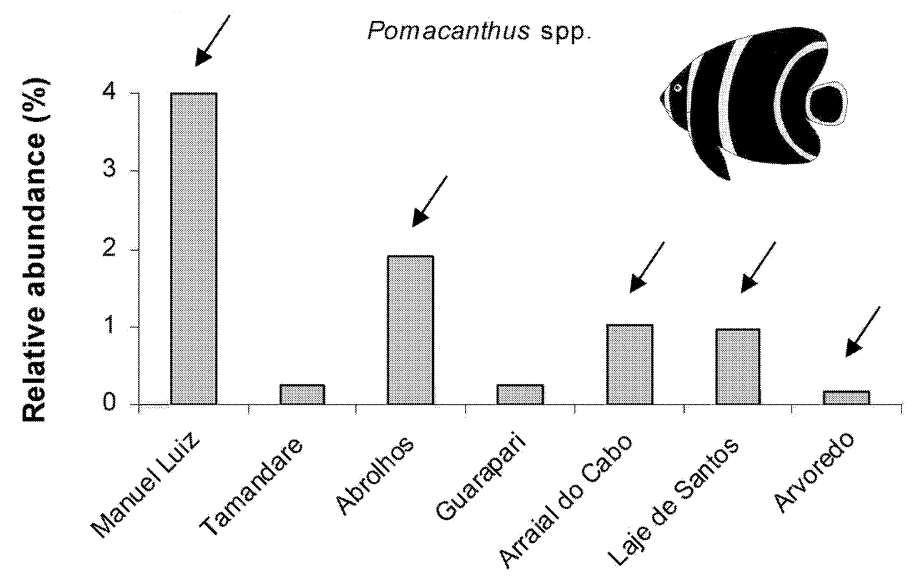

Figure 3. Relative abundance of French and grey angelfish (Pomacanthus spp.) along the Brazilian coast. Refer to Figure 1 for site locations and latitudes. Sites with arrows are marine protected areas. For site descriptions and details on sampling methods see Ferreira et al. (2004).

populations of the angelfish Holacanthus clarionensis at the Revillagigedos island group off the Pacific coast of Mexico (cf. Wood 2001b). Hobbyists frequently favour rarities and/or oddities (e.g. hybrids, distinctive colour morphs or deep-water species), as indicated by the high prices quoted for less readily available species (Sadovy and Vincent 2002). The unique colour morphs (e.g. wholly blue, yellow, or white) of the queen angelfish Holacanthus 'ciliaris' from St. Paul's Rocks are currently the target of such specialised market in Japan (Luiz-Júnior 2003), achieving prices up to US\$ 8900 (Hiroyuki Tanaka, personal communication 2004). If concentrated harvesting of endemic species will continue, and if the risk of extinction of these species will be increased by harvesting, current harvesting practices may well lead to decreased phylogenetic diversity in the long run.

Species with particular reproductive traits (including parental care) are the bulk of ornamental reef fish trade (75.3\%). Sea horses (Hippocampus spp.), long-time favourites of aquarists, are additionally dried in large scale for the souvenir trade, use in folk medicine (Costa-Neto 1999; Warmolts 2000), and even witchcraft (authors' observations). About half of the male sea horses harvested for souvenir trade and traditional medicine in NE Brazil carry eggs in their brood pouch (Rosa, personal communication 2002). Intense harvesting is especially problematic for species with parental care since such exploitation may severely deplete or even wipe out local populations due to low recruitment rates. Additionally, the sea horses suffer greatly from habitat (estuaries and mangroves) pollution or destruction (e.g. landfill for human settlement).

Intensive harvesting may disrupt inter-specific associations such as cleaning symbiosis (review in Côté 2000). The conspicuous colours and small size of reef cleaners, instrumental in their cleaning role on the coral reef (Côté 2000), are 
their most sought-after features for the aquarium trade. Of the ca. 25 species of cleaner fishes and eight cleaner shrimps known from Brazil's coast, all the shrimps and at least 15 fish species are regularly harvested for the ornamental trade (Appendix 1 and 2). The two best studied cleaners in Brazil are the barber goby (Elacatinus figaro) and juvenile French angelfish (Pomacanthus paru), both of which clean numerous and varied client assemblages, from small herbivores to large carnivores (Sazima et al. 1999, 2000) including several economically important species for reef fisheries (groupers, snappers, jacks). A continuous harvesting of cleaner fishes and shrimps, as presently practised in Brazil, may cause an unbalance on the reef's inter-specific associations (e.g. Limbaugh 1961; Bshary 2003; Grutter et al. 2003). Specialised cleaners generally survive for a short time in aquariums due to their distinctive feeding habits, and thus experience a high turnover in the ornamental trade (Wabnitz et al. 2003; authors' personal observations). Harvesting pressure should be alleviated on all life phases of these specialised cleaners, as well as on the juvenile phase of the less specialised ones (Wood 2001b; Monteiro-Neto et al. 2003).

\section{Effects of over-harvesting on ornamental organisms: a study case}

Due to inadequate knowledge, and little understanding of local processes, effects of over-harvesting of ornamental organisms are unknown. The Arraial do Cabo region in Rio de Janeiro, SE Brazil, encompasses about $1500 \mathrm{~km}^{2}$ of rocky shores and was declared a Managed Resource Protected Area in 1997. Before 1997 the ornamental trade strongly affected the region for more than 2 decades. Among the ornamental invertebrates found in Arraial do Cabo, the giant anemone Condylactis gigantea provides an example of the effects of overexploitation. Its abundance before 1990 was about 1-2 individuals per 10$15 \mathrm{~m}^{2}$ (CELF, personal observations prior to 1990). Each anemone (up to $40 \mathrm{~cm}$ wide) may harbour up to 10 cleaner shrimps. Giant anemones occur as solitary individuals, are oviparous and dioecious with a 1:1 sex ratio. They have lecithotrophic planktonic larvae with a presumably short life span in the plankton, and low fecundity (Jennison 1981; Chiappone et al. 2001). This anemone seems to be unable to sustain even a very low level of exploitation due to Allee effects, i.e. individuals became too sparse to achieve significant fertilisation success. At the peak of harvesting (in the early 1990s), about 100 individuals of the giant anemone were taken a day from the Arraial do Cabo reefs. After the collapse of ornamental marine resources in Arraial do Cabo, most collectors migrated northwards to the Espírito Santo State, where about 600 individuals are currently harvested each week (Afonso Jório, personal communication 2002). The last individual of C. gigantea in Arraial do Cabo was recorded about two years ago, despite continued, intense sampling effort (visual census sampling of approximately $6 \mathrm{~h}$ per week - CELF, personal observation 2000-2003). This may be the first documented case of local 
extinction of a relatively large marine organism due to over-exploitation by the ornamental trade in Brazil.

\section{Conservation and management}

There are no specific laws directed to the marine ornamental harvesting in Brazil and such laws are obviously needed to improve domestic fishery law enforcement as well as to prevent illegal trade. The following eight steps are suggested here as of foremost importance to support such law type: (1) Limit the number of licensed collectors and dealers; (2) Give priority to threat assessment of species subject to trade; (3) Establish species-based quotas; (4) Set size limits; (5) Promote adequate collecting methods and storage through the use of quality certifications; (6) Protect rare or key species; (7) Require monthly reports by the dealers; (8) Produce an illustrated guide of the most harvested species (Appendix 1 and 2) that would help officers and custom inspectors to recognise and monitor the trade. Stocks of target species need to be monitored on a reef-by-reef basis due to the variability in abundance of particular species at different localities.

The viability of current trade practices in Brazil should be disputed. Overall, there is a pressing need for basic information on the life history and population dynamics features of the organisms targeted by the marine ornamental trade. Combined with accurate trade data, such information is essential for making more informed decisions for a sustainable collection of marine ornamentals (Wabnitz et al. 2003).

The pressure exerted by the ornamental reef trade may be alleviated through public awareness and certification methods. A good model to follow is outlined in the Marine Aquarium Council's 'Core Ecosystem and Fishery Management Standard' (http://www.aquariumcouncil.org/), an international certification for the quality and sustainability of marine aquarium organisms trade. Model guidelines of this type, if adequately followed, fit well the suggestions made herein for the conservation and management of Brazilian ornamental species. Another important strategy for conservation is the establishment and enforcement of no-take areas, to protect stocks from the selective effects of ornamental and commercial harvesting (Bohnsack 1999). The limited home range and high degree of habitat specificity of many marine ornamental fish species would make the no-take zones a highly effective strategy for the management of these resources (Roberts and Hawkins 2000).

\section{Acknowledgements}

We express our most sincere thanks to D.A. Jório for historical information on the ornamental trade; UNEP-WCMC for providing data; J.-C. Joyeux, J. Van Tassell, N. Polunin, N. Dulvy, D. Vázquez, and I.R. Zalmon for critically 
reading the manuscript; B.M. Feitoza, C.L.S. Sampaio, T.L. Dias, I.L. Rosa (UFPB), M.E. Araújo and M. Nottingham (IMAT), B.P. Ferreira (UFPE/ IBAMA - PE), S.M. Gandolfi, R. Absalão, L.J. Sik (IBAMA - ES), and H. Tanaka for unpublished data; V. Vidal, J. Yaber, C. Sazima, K.I. Gasparini, A.G. Floeter, R.C. Spindola, C.M. Musso, L.A. Rocha, N. Pimenta, W. Krohling, J. Gonçalves, R.B. Francini-Filho, R.L. Moura, A.P. Almeida, C. Bellini (TAMAR), J. Silva Jr. (Centro Golfinho Rotador), for helping in several ways; the Fundação O Boticário de Proteção à Natureza, Padi AWARE Foundation, IBAMA (CEPENE/CEPSUL), AVIDEPA, the Brazilian Navy, the IBAMA managers of Abrolhos and Fernando de Noronha National Marine Parks, the CNPq, FAPESP, FAEP-Unicamp, FINEP/PRONEX, UENF, and the National Center for Ecological Analysis and Synthesis for essential financial and other support.

Appendix 1. Reef fishes most harvested for the aquarium trade in Brazil, selected aspects of their biology, and harvesting methods (classification of fish families follows Nelson (1994)).

\begin{tabular}{|c|c|c|c|}
\hline Families and species & Reproductive biology ${ }^{a}$ & $\begin{array}{l}\text { Cleaning } \\
\text { symbiosis }\end{array}$ & $\begin{array}{l}\text { Harvesting } \\
\text { methods }\end{array}$ \\
\hline \multicolumn{4}{|l|}{ Ginglymostomatidae } \\
\hline Ginglymostoma cirratum $^{\mathrm{b}}$ & $\begin{array}{l}\text { Internal fertilisation; } \\
\text { live bearing }\end{array}$ & & $\mathrm{A}, \mathrm{Sf}, \mathrm{H}$ \\
\hline \multicolumn{4}{|l|}{ Narcinidae } \\
\hline Narcine brasiliensis & $\begin{array}{l}\text { Internal fertilisation; } \\
\text { live bearing }\end{array}$ & & $\mathrm{A}, \mathrm{T}$ \\
\hline \multicolumn{4}{|l|}{ Rhinobatidae } \\
\hline Rhinobatus spp. & $\begin{array}{l}\text { Internal fertilisation; } \\
\text { live bearing }\end{array}$ & & $\mathrm{A}, \mathrm{T}$ \\
\hline Zapteryx brevirostris & $\begin{array}{l}\text { Internal fertilisation; } \\
\text { live bearing }\end{array}$ & & $\mathrm{A}, \mathrm{T}$ \\
\hline \multicolumn{4}{|l|}{ Muraenidae } \\
\hline \multirow{2}{*}{\multicolumn{4}{|c|}{ Ophichthidae }} \\
\hline & & & \\
\hline Myrichthys breviceps & & & A \\
\hline Myrichthys ocellatus & & & A \\
\hline \multicolumn{4}{|l|}{ Bythitidae } \\
\hline $\begin{array}{l}\text { Stygnobrotula latebricola } \\
\text { Antennariidae }\end{array}$ & Live-bearer & & A \\
\hline Antennarius multiocellatus ${ }^{\mathrm{b}}$ & Nest guarding & & A, $\mathrm{T}$ \\
\hline Antennarius striatus $^{\mathrm{b}}$ & Nest guarding & & $\mathrm{A}, \mathrm{T}$ \\
\hline \multicolumn{4}{|l|}{ Ogcocephalidae } \\
\hline \multicolumn{4}{|l|}{ Syngnathidae } \\
\hline Hippocampus aff. erectus ${ }^{\mathrm{d}, \mathrm{b}}$ & $\begin{array}{l}\text { Internal fertilisation; } \\
\text { parental care }\end{array}$ & & $\mathrm{A}+, \mathrm{S}, \mathrm{T}$ \\
\hline Hippocampus aff. reidi ${ }^{\mathrm{d}, \mathrm{b}}$ & $\begin{array}{l}\text { Internal fertilisation; } \\
\text { parental care }\end{array}$ & & $\mathrm{A}+, \mathrm{S}, \mathrm{T}$ \\
\hline Microphis eigenmanni ${ }^{\mathrm{d}, \mathrm{b}}$ & $\begin{array}{l}\text { Internal fertilisation; } \\
\text { parental care }\end{array}$ & & A \\
\hline
\end{tabular}


Appendix 1. (Continued)

\begin{tabular}{|c|c|c|c|}
\hline Families and species & Reproductive biology ${ }^{\mathrm{a}}$ & $\begin{array}{l}\text { Cleaning } \\
\text { symbiosis }\end{array}$ & $\begin{array}{l}\text { Harvesting } \\
\text { methods }\end{array}$ \\
\hline \multicolumn{4}{|l|}{ Serranidae } \\
\hline Epinephelus itajara ${ }^{\mathrm{c}, \mathrm{b}}$ & $\begin{array}{l}\text { Sex change, } \\
\text { spawning aggregation }\end{array}$ & & $\mathrm{A}, \mathrm{Sf}, \mathrm{T}, \mathrm{H}$ \\
\hline Liopropoma carmabi $^{\mathrm{c}}$ & & & $\mathrm{A}+$ \\
\hline \multicolumn{4}{|l|}{ Grammatidae } \\
\hline Gramma brasiliensis $^{\mathrm{d}}$ & mouth-brooder & occasional (J-A) & $\mathrm{A}+$ \\
\hline \multicolumn{4}{|l|}{ Apogonidae } \\
\hline Apogon americanus ${ }^{\mathrm{d}}$ & Mouth-brooder & & A \\
\hline Apogon planifrons & Mouth-brooder & & A \\
\hline Apogon pseudomaculatus & Mouth-brooder & & A \\
\hline Phaeoptyx pigmentaria & Mouth-brooder & & A \\
\hline \multicolumn{4}{|l|}{ Haemulidae } \\
\hline Anisotremus moricandi ${ }^{\mathrm{d}}$ & & Habitual? (J) & $\mathrm{A}, \mathrm{Sf}, \mathrm{H}$ \\
\hline Anisotremus virginicus & & Habitual (J) & A, Sf, H \\
\hline \multicolumn{4}{|l|}{ Sciaenidae } \\
\hline Equetus lanceolatus ${ }^{\mathrm{c}}$ & & & $\mathrm{A}+$ \\
\hline Pareques acuminatus & & & A \\
\hline \multicolumn{4}{|l|}{ Cirrhitidae } \\
\hline Amblycirrhitus pinos & & & A \\
\hline \multicolumn{4}{|l|}{ Chaetodontidae } \\
\hline Chaetodon ocellatus & Spawning aggregation & & A \\
\hline Chaetodon sedentarius & Spawning aggregation & Occasional (A) & A \\
\hline Chaetodon striatus & Spawning aggregation & Occasional (A) & A \\
\hline Prognathodes brasiliensis $^{\mathrm{d}}$ & & & $\mathrm{A}+$ \\
\hline Prognathodes obliquus ${ }^{\mathrm{d}, \mathrm{c}}$ & & & A \\
\hline Prognathodes guyanensis ${ }^{\mathrm{d}}$ & & & A \\
\hline \multicolumn{4}{|l|}{ Pomacanthidae } \\
\hline Centropyge aurontonotus ${ }^{\mathrm{d}}$ & Sex change; harem & & $\mathrm{A}+$ \\
\hline Holacanthus ciliaris & Sex change & Occasional (J) & $\mathrm{A}+$ \\
\hline Holacanthus tricolour & Sex change & Occasional (J) & $\mathrm{A}+$ \\
\hline Pomacanthus arcuatus & Sex change & Habitual? (J) & $\mathrm{A}+$ \\
\hline Pomacanthus paru & Sex change & Habitual (J) & $\mathrm{A}+$ \\
\hline \multicolumn{4}{|l|}{ Pomacentridae } \\
\hline Abudefduf saxatilis & Nest guarding & Occasional (J) & A \\
\hline Chromis flavicauda $^{\mathrm{d}}$ & Nest guarding & & $\mathrm{A}+$ \\
\hline Chromis jubauna ${ }^{\mathrm{d}}$ & Nest guarding & & $\mathrm{A}+$ \\
\hline Chromis multilineata & Nest guarding & & A \\
\hline Microspathodon chrysurus & Nest guarding & Occasional (J) & $\mathrm{A}+$ \\
\hline Stegastes fuscus ${ }^{\mathrm{d}}$ & Nest guarding & & A \\
\hline Stegastes pictus ${ }^{\mathrm{d}}$ & Nest guarding & & A \\
\hline Stegastes variabilis & Nest guarding & & $\mathrm{A}+$ \\
\hline \multicolumn{4}{|l|}{ Labridae } \\
\hline Bodianus pulchellus & Sex change; harem & $\begin{array}{l}\text { Habitual (J), } \\
\text { occasional (A) }\end{array}$ & $\mathrm{A}+$ \\
\hline Bodianus rufus & Sex change; harem & $\begin{array}{l}\text { Habitual (J), } \\
\text { occasional (A) }\end{array}$ & $\mathrm{A}+$ \\
\hline Halichoeres bivittatus & Sex change; harem & Occasional (J) & A \\
\hline Halichoeres brasiliensis $^{\mathrm{d}}$ & Sex change; harem & Occasional $(\mathbf{J})$ & A \\
\hline
\end{tabular}


Appendix 1. (Continued)

\begin{tabular}{|c|c|c|c|}
\hline Families and species & Reproductive biology ${ }^{\mathrm{a}}$ & $\begin{array}{l}\text { Cleaning } \\
\text { symbiosis }\end{array}$ & $\begin{array}{l}\text { Harvesting } \\
\text { methods }\end{array}$ \\
\hline Halichoeres aff. cyanocephalus $\mathrm{d}^{\mathrm{d}}$ & Sex change; harem & Habitual (J) & $\mathrm{A}+$ \\
\hline Halichoeres aff. maculipinna ${ }^{\mathrm{d}}$ & Sex change; harem & Occasional (J) & A \\
\hline Halichoeres poeyi & Sex change; harem & Occasional (J) & A \\
\hline Thalassoma noronhanum $\mathrm{d}$ & Sex change; harem & Habitual (J) & A \\
\hline \multirow{2}{*}{\multicolumn{3}{|c|}{ Scaridae }} & A \\
\hline $\begin{array}{l}\text { Scaridae } \\
\text { Scarus zelindae }\end{array}$ & Sex change; harem & & \\
\hline Sparisoma tuiupiranga ${ }^{\mathrm{d}}$ & Sex change; harem & & $\mathrm{A}, \mathrm{Sf}$ \\
\hline \multicolumn{4}{|l|}{ Opistognathidae } \\
\hline Opistognathus lonchurus & Mouth-brooder & & A \\
\hline Opistognathus sp. n. ${ }^{\mathrm{d}}$ & Mouth-brooder & & $\mathrm{A}+$ \\
\hline \multicolumn{4}{|l|}{ Labrisomidae } \\
\hline 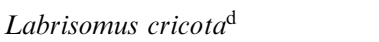 & Harem; nest guarding & & A \\
\hline Labrisomus nuchipinnis & Harem; nest guarding & & $\mathrm{A}$ \\
\hline Malacoctenus sp. $\mathrm{n}{ }^{\mathrm{d}}$ & Harem; nest guarding & & A \\
\hline \multicolumn{4}{|l|}{ Blenniidae } \\
\hline Ophioblennius trinitatis ${ }^{\mathrm{d}}$ & Nest guarding & & A \\
\hline Parablennius marmoreus & Nest guarding & & A \\
\hline Scartella cf. cristata $^{\mathrm{d}}$ & Nest guarding & & A \\
\hline \multicolumn{4}{|l|}{ Gobiidae } \\
\hline Elacatinus figaro $^{\mathrm{d}}$ & $\begin{array}{l}\text { Nest guarding; } \\
\text { monogamous }\end{array}$ & Habitual (J-A) & $\mathrm{A}+$ \\
\hline \multicolumn{4}{|l|}{ Microdesmidae } \\
\hline Ptereleotris randalli ${ }^{\mathrm{d}}$ & Nest guarding & & A \\
\hline \multicolumn{4}{|l|}{ Acanthuridae } \\
\hline Acanthurus coeruleus & & & A \\
\hline \multicolumn{4}{|l|}{ Balistidae } \\
\hline Balistes vetula & Nest guarding & & $\mathrm{A}, \mathrm{Sf}$ \\
\hline \multicolumn{4}{|l|}{ Monacanthidae } \\
\hline Cantherines macrocerus & Monogamous & & A \\
\hline Cantherines pullus & Monogamous & & A \\
\hline \multicolumn{4}{|l|}{ Ostraciidae } \\
\hline Acanthostracion polygonius & & & A \\
\hline Acanthostracion quadricornis & & & A \\
\hline \multicolumn{4}{|l|}{ Tetraodontidae } \\
\hline Canthigaster figueiredoi ${ }^{\mathrm{d}}$ & Monogamous & & A \\
\hline \multicolumn{4}{|l|}{ Diodontidae } \\
\hline Cyclichthys spinosus $^{\mathrm{d}}$ & & & A \\
\hline Diodon holocanthus & & & A \\
\hline
\end{tabular}

(a) Reproductive biology associated with increased vulnerability to extinction; (b) Estuarine dependent; (c) Rare, defined as recorded in about $10 \%$ or less of dives at a given site, or dwelling in depths greater than $40 \mathrm{~m}$ (thus hardly available for collectors), or vagrant in a given area; (d) Endemic to the Brazilian Province or to Brazil's coast plus the southern tip of the Caribbean; Cleaning symbiosis: $\mathrm{A}=$ adult; $\mathrm{J}=$ juvenile; Harvesting methods: $\mathrm{A}=$ Aquarium trade; $\mathrm{A}+=$ High pressure; $\mathrm{S}=$ Souvenir; $\mathrm{Sf}=$ Spearfishing; $\mathrm{T}=$ Trawling; $\mathrm{H}=$ Hook and Line. 
Appendix 2. Invertebrates most harvested for the aquarium and souvenir trade in Brazil, selected aspects of their biology, and harvesting methods.

\begin{tabular}{|c|c|c|}
\hline Species & Biology & Harvesting methods \\
\hline \multicolumn{3}{|l|}{ Cnidarians (Stony Corals) } \\
\hline Favia gravida ${ }^{\mathrm{a}}$ & Reef builder & $\mathrm{A}, \mathrm{S}$ \\
\hline Madracis decactis & & A \\
\hline Meandrina braziliensis ${ }^{\mathrm{a}}$ & & $\mathrm{S}, \mathrm{A}$ \\
\hline Montastrea cavernosa & & $\mathrm{S}, \mathrm{A}$ \\
\hline Mussismilia braziliensis ${ }^{\mathrm{a}}$ & Reef builder & $\mathrm{S}, \mathrm{A}$ \\
\hline Mussismilia hartii ${ }^{\mathrm{a}}$ & Reef builder & $\mathrm{S}, \mathrm{A}$ \\
\hline Mussismilia hispida ${ }^{\mathrm{a}}$ & Reef builder & $\mathrm{S}, \mathrm{A}$ \\
\hline Porites branneri & & $\mathrm{S}, \mathrm{A}$ \\
\hline Scolymia wellsi & Sand dweller & A \\
\hline Siderastrea stellata ${ }^{\mathrm{a}}$ & Reef builder & $\mathrm{A}, \mathrm{S}$ \\
\hline \multicolumn{3}{|l|}{ Cnidarians (Fire Corals) } \\
\hline Millepora braziliensis ${ }^{\mathrm{a}}$ & Reef builder & $\mathrm{S}+, \mathrm{A}$ \\
\hline Millepora alcicornis & Reef builder & $\mathrm{S}+, \mathrm{A}$ \\
\hline \multicolumn{3}{|l|}{ Cnidarians (Octocorals) } \\
\hline Carijoa riisei & & A \\
\hline Heterogorgia uatumani ${ }^{\mathrm{a}}$ & & A \\
\hline Lophogorgia punicea ${ }^{\mathrm{a}}$ & & A \\
\hline Lophogorgia violacea ${ }^{\mathrm{a}}$ & & A \\
\hline Muricea flamma ${ }^{\mathrm{a}}$ & & $\mathrm{S}, \mathrm{A}$ \\
\hline Muriceopsis sulphurea ${ }^{\mathrm{a}}$ & & A \\
\hline Phyllogorgia dilatata $^{\mathrm{a}}$ & & $\mathrm{S}+, \mathrm{A}$ \\
\hline Plexaurella grandiflor $a^{\mathrm{a}}$ & & A \\
\hline Plexaurella regia ${ }^{\mathrm{a}}$ & & A \\
\hline \multicolumn{3}{|l|}{ Cnidarians (Black Corals) } \\
\hline Cirripathes spp. ${ }^{\mathrm{b}}$ & Deep reefs & $\mathrm{S}$ \\
\hline \multicolumn{3}{|c|}{ Cnidarians (Sea Anemones) } \\
\hline Actinoporus sp. & & A \\
\hline Alicia mirabilis & & A \\
\hline Bellactis ilkalysae & Shallow reefs & A \\
\hline Condylactis gigantea ${ }^{\mathrm{b}}$ & Station for cleaners & $\mathrm{A}+$ \\
\hline Discossoma spp. & & A \\
\hline \multicolumn{3}{|l|}{ Cnidarians (Zoanthids) } \\
\hline Palythoa caribaeorum & & A \\
\hline Zoanthus spp. & & A \\
\hline \multicolumn{3}{|l|}{ Mollusks } \\
\hline Cassis tuberosa & & $\mathrm{S}, \mathrm{T}$ \\
\hline Charonia variegata ${ }^{\mathrm{b}}$ & & $\mathrm{S}, \mathrm{T}$ \\
\hline Conus spp. & Venomous predator & $\mathrm{A}, \mathrm{S}$ \\
\hline Cyphoma macumba & & $\mathrm{S}$ \\
\hline Cyphoma signatum & & $\mathrm{S}$ \\
\hline Cypraea zebra & & $\mathrm{S}$ \\
\hline Lyropecten nodosus & & $\mathrm{S}$ \\
\hline Octopus vulgaris & Key predator on crabs & A \\
\hline Spondylus americanus & & $\mathrm{S}+$ \\
\hline Strombus gigas ${ }^{\mathrm{b}}$ & & $\mathrm{S}+, \mathrm{T}$ \\
\hline
\end{tabular}


Appendix 2. (Continued)

\begin{tabular}{|c|c|c|}
\hline Species & Biology & Harvesting methods \\
\hline \multicolumn{3}{|l|}{ Polychaetes } \\
\hline Spirobranchus spp. & & A \\
\hline \multicolumn{3}{|l|}{ Crustaceans } \\
\hline Brachycarpus cf. biunguinculatus & Cleaner? & A \\
\hline Calcinus tibicen & & $\mathrm{A}, \mathrm{T}$ \\
\hline Cinetorhynchus rigens & & A \\
\hline Dardanus venosus & & $\mathrm{A}, \mathrm{T}$ \\
\hline Hoplometopus antillensis ${ }^{\mathrm{b}}$ & & $\mathrm{A}+$ \\
\hline Lysmata grabhami & cleaner & A \\
\hline Lysmata wurdemanni ${ }^{\mathrm{b}}$ & cleaner & A \\
\hline Periclimenes aff. pederson $i^{\mathrm{b}}$ & Cleaner & A \\
\hline Periclimenes aff. yucatanicus ${ }^{\mathrm{b}}$ & Cleaner & A \\
\hline Petrochirus diogenes & & A, S \\
\hline Platypodiella spectabilis & & A \\
\hline Stenopus hispidus & Cleaner & $\mathrm{A}+$ \\
\hline Stenopus scutellatus ${ }^{\mathrm{b}}$ & Cleaner & A \\
\hline Stenorhynchus seticornis & Cleaner? & $\mathrm{A}+$ \\
\hline Thor aff. amboinensis ${ }^{\mathrm{b}}$ & Cleaner? & A \\
\hline \multicolumn{3}{|l|}{ Echinoderms } \\
\hline Astrophyton sp. & & A \\
\hline Echinaster spp. & & A \\
\hline Echinometra lucunter & Key herbivore & $\mathrm{S}$ \\
\hline Eucidaris tribuloides & Key herbivore & $\mathrm{A}+, \mathrm{S}$ \\
\hline Linckia guildingii & & A \\
\hline Meoma ventricosa & & $\mathrm{S}$ \\
\hline Narcisia trigonaria & & A \\
\hline Ophioderma spp. & & A \\
\hline Oreaster reticulatus & & $\mathrm{S}+$ \\
\hline Tripneustes ventricosus & & $\mathrm{S}$ \\
\hline
\end{tabular}

(a) Endemic to the Brazilian Province; (b) Rare, defined as recorded in about $10 \%$ or less of dives at a given site, or dwelling in depths greater than $40 \mathrm{~m}$ (thus hardly available for collectors), or vagrant in a given area; Harvesting pressure: $\mathrm{A}=$ Aquarium trade; $\mathrm{A}+=$ High pressure; $\mathrm{S}=$ Souvenir trade; $\mathrm{T}=$ Trawling.

\section{References}

Andrews C. 1990. The ornamental fish trade and fish conservation. J. Fish Biol. 37: 53-59.

Biffar M. 1997. The worldwide trade in ornamental fish, Current status: trends and problems. Bull. Eur. Assoc. Fish Pathol. 17: 201-204.

Bohnsack J.A. 1999. Incorporating no-take marine reserves into precautionary management and stock assessment. Proceedings 5th NMFS NSAW. NOAA Technical Memo. NMFS-F/SPO 40: 8-16.

Bshary R. 2003. The cleaner wrasse, Labroides dimidiatus is a key organism for reef fish diversity at Ras Mohammed National Park, Egypt. J. Anim. Ecol. 72: 169-176.

Chapman F.A., Fitz-Coy S.A., Thunberg E.M. and Adams C.M. 1997. United States of America trade in ornamental fish. J. World Aquacult. Soc. 28: 1-10. 
Chiappone M., Swanson D.W. and Miller S.L. 2001. Condylactis gigantea - a giant comes under pressure from the aquarium trade in Florida. Reef Encounter 30: 29-31.

Costa-Neto E.M 1999. Healing with animals in Feira de Santana City, Bahia, Brazil. J. Ethnopharmacol. 65: 225-230.

Côté I.M 2000. Evolution and ecology of cleaning symbioses in the sea. In: Gibson R.N. and Barnes M. (eds), Oceanography and Marine Biology: An Annual Review. Taylor and Francis, London, pp. 311-355.

Davenport K.E. 1996. Characteristics of the current international trade in ornamental fish, with special reference to the European Union. Scientific and Technical Review of the Office International des Epizooties 5: 435-443.

Dias T.L., Rosa I.L. and Baum J.K. 2002. Threatened fishes of the world: Hippocampus erectus Perry, 1810 (Syngnathidae). Environ. Biol. Fish. 65: 326.

Edwards A.J. and Shepherd A.D. 1992. Environmental implications of aquarium-fish collection in the Maldives, with proposals for regulation. Environ. Conserv. 19: 61-72.

Floeter S.R. 2003. Brazilian Reef Fishes: Trophic and Community Structure Patterns, Latitudinal Gradients and Ornamental Trade. Universidade Estadual do Norte Fluminense, PhD Thesis, Rio de Janeiro, Brazil, p.138.

Ferreira C.E.L., Floeter S.R., Gasparini J.L., Ferreira B.P. and Joyeux J.C. 2004. Trophic structure patterns of Brazilian reef fishes: a latitudinal comparison. J. Biogeogr. 31: 1093-1106.

Friedlander A.M. 2001. Essential fish habitat and the effective design of marine reserves: application for marine ornamental fishes. Aquar. Sci. Conserv. 3: 135-150.

Grutter A.S., Murphy J.M. and Choat J.H. 2003. Cleaner fish drives local fish diversity on coral reefs. Curr. Biol. 13: 64-67.

Harmelin-Vivien M.L. 2002. Energetics and fish diversity on coral reefs. In: Sale P.F. (ed), Coral Reef Fishes: Dynamics and Diversity in a Complex Ecosystem. Academic Press, San Diego, pp. 265-274.

Hawkins J.P., Roberts C.M. and Clark V. 2000. The threatened status of restricted-range coral reef fish species. Anim. Conserv. 3: 81-88.

Hill S.M. 1998. Spongivory on Caribbean reefs releases corals from competition with sponges. Oecologia 117: 143-150.

IBAMA 2000. Reunião técnica sobre o estado da arte da pesquisa e do ordenamento da pesca de peixes ornamentais marinhos no Brasil. Relatório Técnico CEPENE/IBAMA Tamandaré, Pernambuco, Brazil, pp. 42.

Jennison B.L. 1981. Reproduction in three species of sea anemones from Key West, Florida. Can. J. Zool. 59: 1708-1719.

Leão Z.M.A.N. and Dominguez J.M.L. 2000. Tropical coast of Brazil. Mar. Pollut. Bull. 41: 112122.

Leis J.M. 1991. The pelagic stage of reef fishes: the larval biology of coral reef fishes. In: Sale P.F. (ed), The Ecology of Fishes on Coral Reefs. Academic Press, San Diego, pp. 183-230.

Leis J.M. 2002. Pacific coral-reef fishes: the implications of behaviour and ecology of larvae for biodiversity and conservation, and a reassessment of the open population paradigm. Environ. Biol. Fish. 65: 199-208.

Limbaugh C. 1961. Cleaning symbiosis. Sci. Am. 205: 42-49.

Luiz-Júnior O.J. 2003. The quest for ciliaris morphs. In: Debelius H., Tanaka H. and Kuiter R.H. (eds), Angelfishes: A Comprehensive Guide to Pomacanthidae. TMC Publishing, Chorleywood, UK, 208 pp.

Monteiro-Neto C., Ferreira B.P., Rosa I.L., Rocha L.A., Araújo M.E., Guimarães R.Z.P., Floeter S.R. and Gasparini J.L. 2000. The Marine Aquarium Fisheries and Trade in Brazil. A preliminary report submitted to the IUCN. Fortaleza, Brazil.

Monteiro-Neto C., Cunha F.E.A., Nottingham M.C., Araújo M.E., Rosa I.L. and Barros G.M.L. 2003. Analysis of the marine ornamental fish trade at Ceará State, northeast Brazil. Biodiv. Conserv. 12: 1287-1295.

Nelson J.S. 1994. Fishes of the World, 3rd ed. John Wiley \& Sons, New York, USA, 600 pp. 
Nottingham M.C., Cunha F.E.A. and Monteiro-Neto C. 2000. Captura de peixes ornamentais marinhos no Estado do Ceará. Arquivos de Ciências do Mar, Fortaleza 33: 119-124.

Roberts C.M. and Hawkins J.P. 2000. Fully-protected marine reserves: a guide. WWF Endangered Seas Campaign, 1250 24th Street, NW, Washington, DC 20037, USA, [WWW. Document] http://www.panda.org/enengeredseas/.

Sadovy Y.J. and Vincent A.C.J. 2002. Ecological issues and the trades in live reef fishes. In: Sale P.F. (ed), Coral Reef Fishes: Dynamics and Diversity in a Complex Ecosystem. Academic Press, San Diego, pp 391-420.

Sazima I., Sazima C., Francini-Filho R.B. and Moura R.L. 2000. Daily cleaning activity and diversity of clients of the barber goby, Elacatinus figaro, on rocky reefs in southeastern Brazil. Environ. Biol. Fish. 59: 69-77.

Sazima I., Moura R.L. and Sazima C. 1999. Cleaning activity of juvenile angelfish, Pomacanthus paru, on the reefs of the Abrolhos Archipelago, western South Atlantic. Environ. Biol. Fish. 56: 399-407.

Wabnitz C., Taylor M., Green E. and Razak T. 2003. From Ocean to Aquarium. UNEP-WCMC, Cambridge, UK, 65 pp.

Warmolts D.I. 2000. Marine medicinals in the aquarium trade. In: Moreau M.A., Hall M.J. and Vincent A.C.J. (eds), The Workshop on the Management and Culture of Marine Species Used in Traditional Medicines. Project Seahorse, Montreal, Canada, pp. 107-109.

Wood E.M. 1985. Exploitation of Coral Reef Fishes for the Aquarium Trade. Marine Conservation Society, Ross-on-Wye, UK, $121 \mathrm{pp}$

Wood E.M. 2001a. Collection of Coral Reef Fish for Aquaria: Global Trade, Conservation Issues and Management Strategies. Marine Conservation Society, Ross-on-Wye, UK, 80 pp.

Wood E.M. 2001b. Global Advances in Conservation and Management of Marine Ornamental Resources. Aquar. Sci. Conserv. 3: 65-77. 